\title{
NEW REFUGEE INTERVIEWS FOR HUMANITARIAN AND COMPASSIONATE CONSIDERATIONS: COSMETICS AND REALITIES
}

\author{
Edward Opoku-Dapaah, \\ Department of Sociology, York University
}

The past decade saw an unprecedented increment in the number of asylum seekers in Canada creating backlogs in the processing of claims. On December 28th, 1988, the Federal Minister of Immigration and Employment, Hon. Barbara McDougall announced there were approximately 85,000 backlog refugeecases;current estimates place the volume at 100,000 . In order to handle the immense volume of applications, the Federal government established a new refugee determination system effective from January 1989, under Bill C-55.

Claimants appear before a special two-person panel, composed of an adjudiontor and a member of the refugee division of the Immigration and Refugee Bond(IIB), who must bothagree to reject a claim. If either panel member determines a credible basis for a chim the applicant will beallowed to apply for permanent reddence. Before attending the parel hearings, however, refugee claimants have to attend interviews to have their cases initially assessed by immigration officers, to determine whether there exist any humanitarian and compesionate grounds for scoepting thet cintina

In thellight of a recent Federal Court lectsion that ruch refugee interviews vere insdequate for the consideration of potential claimants on "humanitarian" and "compassionate" grounds, the Refugee Bacidog Clearance Centre ha been compelled to arrange new iniaviewn. The importance of auch a novecunnot beunderestimated. Candh s committed to gramanteeing all refugee Inimants a fit heartug. Among many ther things, the assessment for umanitarian and compassionate rounds ensures that refugee claims hich possess these ingredients will be leali with fastenough to enabletheboard to save time and resources for dealing with the tremendous backlog.

However, after interviews with clients who have appeared before this new review process, our impresion is that it not only lacks the crucial
"... this acceptance record is terribly inappropriate, and a woeful indication of the sorrowful state of the new interviews. The low acceptance rate creates the embarrassing illusion that the cases of these clients are profoundly inadequate for consideration on humanitarian grounds."

characteristics which can adequately encure condderation on humanitarian and compasionate ground, but also servesesa calculated attempt to dreces up the whole process of refugee determination while masking the inherent contradictions.

Of the 2,395 cifents who appeared at the new interviews between late March and late May, 1990, only 587 of them were accepled. This might appear acceptable to some commentators. Hownever, to us this acceptance record is terribly inappropitate, and a woeful indication of the somowitul state of the new interviews. The low acceptance rate creates the embarmasing illusion that the cases of these clients are profoundly inadequate for consideration on humeniturian grounda. Inourestimation, it is the very natureand structure of these interviews which impede the acceptability of clients.

Our focus in this article is the examination of these new interviews in order to bring out the inherent weakness and its unsuitability for consideration of refugee claimants on both humanitarian and compasionate grounds. Firt, the summons to these interviews state: Interpreters will not be provided. Should you require language assistance please bring a friend or relative to interpret for you. "Impilcity the Refugee Determination Boand is declaring that it is not its responsibility to ensure that clients who are not proficlent in English will understand the procesdings. Triking into consideration that Englich is not the first language of an overwhelming majority of auch clients, wach a practice makes nonsense of the mandate of the whole interview - "consideration of clients on the bads of humanitarian and compassionate grounds". For those clients who do not have fitends or relatives who can adequately and appropitately provide transiation under atiofuctory lerme, the only altemative is to dit through the sescion without graping the main import of a cruclal determination of thet fate.

Secondly, the sescions have been hasty, rushed and short-lived. A typical session runs for fffteen minutes This is too compreseed to realietically consider the fate of people on the bats of humanitarian and compasolonate grounda Cients we in levvieved for til articlesthliad that etnce the wholescuion is 20 short if b not worth paying ove $\$ 500$ to solicit services of a lawyer. The structure of the supposedly fair interviews has become a fetter discouraging solicitation of legal representation, a crucial aspect of justice and faimes. 